\title{
DIMENSIONAL, OSMOTIC, AND CHEMICAL CHANGES OF ERYTHROCYTES IN STORED BLOOD. II. EVALUATION OF SEVERAL ACID AND NEUTRAL PRESERVATION MIXTURES. EFFECT OF STORAGE AT $25^{\circ} \mathrm{C}$. IN ALSEVER'S SOLUTION ${ }^{1}$
}

\author{
By S. RAPOPORT \\ WITH THE TECHNICAL ASSISTANCE OF MARY WING \\ (From the Children's Hospital Research Foundation and the Department of Pediatrics, Uni- \\ versity of Cincinnati College of Medicine, Cincinnati)
}

(Received for publication August 31, 1946)

In this communication are summarized several phases of a program aimed at assessing the value of in vitro methods for gauging and improving preservative techniques (1). A series of experiments is reported on the effect on the preservation of erythrocytes of variations in the extent of dilution and acidification from the original acid citrateglucose (ACD-I) solution $(2,3)$. The experiments yielded only negative results. They are reported as a record for other workers in the field and because they bear on the theory of permeability of the red cell. A second phase deals with a comparison between ACD-I and Alsever's solution (4) with respect to the preservation of red cells, undertaken because of the extensive use of Alsever's solution by the United States Army in the European Theater of Operations. Because it was claimed that blood can be stored satisfactorily without refrigeration in Alsever's solution (5) an experiment on the effect of storage at $25^{\circ} \mathrm{C}$. on the preservation of red cells was also included. Finally, a few data are reported on the in vitro changes of blood stored in De Gowin's (6) and McGill II (7) solution. These neutral solutions entail dilution of blood to the extent of 150 and 50 per cent, respectively.

Since many of the changes observed in this study are similar to those reported in the preceding communication, the report for the most part is limited to 5 indices: (1) hemolysis in 0.6 per cent $\mathrm{NaCl}$ solution, (2) increase of thickness, (3) changes in adenosine triphosphate content, (4) glycolysis rate and (5) potassium concentra-

1 The work described in this paper was done under a contract, recommended by the Committee on Medical Research, between the Office of Scientific Research and Development and the Children's Hospital of Cincinnati. tion of cells. In addition, calculations and data on the osmotic characteristics of the preservatives studied and the changes in corpuscular volume of erythrocytes are presented.

\section{METHODS AND MATERIALS}

The technique of collecting and distributing the blood samples and the analytical methods used have been described previously (1).

TABLE I

Composition of acid citrate-glucose mixtures for the preservation of whole blood

\begin{tabular}{|c|c|c|c|c|c|c|c|}
\hline Mixture & $\underset{\text { citrate* }}{\mathrm{Na}}$ & $\begin{array}{c}\text { Citric } \\
\text { ac.* }\end{array}$ & $\begin{array}{l}\text { Glu- } \\
\text { cose* }\end{array}$ & $\frac{\text { Citr. ac. }}{\mathrm{Na} \text { citr. }}$ & pH & $\begin{array}{c}\text { Vol. } \\
\text { added } \\
\text { to } \\
100 \\
\text { ml. } \\
\text { blood }\end{array}$ & $\underset{\text { pH }}{\text { Plasma }}$ \\
\hline & $\begin{array}{c}\text { grams } \\
\text { per } \\
100 \mathrm{ml} .\end{array}$ & $\begin{array}{c}\text { grams } \\
\text { per } \\
100 \mathrm{ml} .\end{array}$ & $\begin{array}{l}\text { grams } \\
\text { per } \\
100 \mathrm{ml} .\end{array}$ & $\underset{\text { ratio }}{\text { Molar }}$ & & ml. & \\
\hline $\begin{array}{l}\text { ACD-I } \\
\text { ACD-IA } \\
\text { ACD-IB } \\
\text { ACD-IC } \\
\text { ACD-ID } \\
\text { ACD-IE } \\
\text { ACD-IF }\end{array}$ & $\begin{array}{l}1.33 \\
3.32 \\
1.11 \\
2.00 \\
0.88 \\
1.88 \\
1.33\end{array}$ & $\begin{array}{l}0.47 \\
1.18 \\
0.63 \\
0.78 \\
0.80 \\
1.07 \\
0.60^{* *}\end{array}$ & $\begin{array}{l}3.00 \\
7.50 \\
3.00 \\
5.00 \\
3.00 \\
5.00 \\
3.00\end{array}$ & $\begin{array}{l}0.49 \\
0.49 \\
0.80 \\
0.55 \\
1.27 \\
0.81 \\
0.49\end{array}$ & $\begin{array}{l}5.03 \\
5.03 \\
4.62 \\
4.86 \\
4.17 \\
4.54\end{array}$ & $\begin{array}{l}25 \\
10 \\
25 \\
15 \\
25 \\
15 \\
25\end{array}$ & $\begin{array}{l}7.03 \\
7.05 \\
6.82 \\
7.00 \\
6.67 \\
6.84 \\
7.05\end{array}$ \\
\hline
\end{tabular}

* Tri-sodium citrate $\cdot 2 \mathrm{H}_{2} \mathrm{O}$, citric acid $\cdot \mathrm{H}_{2} \mathrm{O}$, glucose anhydrous.

${ }^{* *}$ Lactic acid.

In Table $I$ is shown the composition of the various ACD solutions studied. It may be seen that they covered a range of dilution of blood from 10 to 25 per cent, which is the most useful range and of $\mathrm{pH}$ from 7.0 to 6.8. In solution ACD-IF, citric acid was replaced by an equivalent amount of lactic acid with a view to exploring the possibility that accumulation of lactic acid may represent the limiting factor in the preservation of red cells. The composition of De Gowin's and McGill II solutions has been given in the literature $(4,6,7)$ and is therefore omitted. A few words of comment with regard to Alsever's solution may be in order: This solution as originally described had the composition: sodium citrate 0.57 , 
sodium chloride 0.42 , dextrose 1.87 grams per $100 \mathrm{ml}$. to be added in equal volume to blood. During the war the Baxter company modified it as follows: sodium citrate 0.80 , sodium chloride 0.42 , dextrose 2.05 grams per 100 ml., with the addition of 0.0075 gram of citric acid, resulting in a pH of the mixture of 6.8. This modification, designated simply as Alsever's solution in the following discussion, was the one studied in this laboratory. Later the same company modified the solution still further by adding sufficient citric acid to bring the $\mathrm{pH}$ to 6.0 .

\section{RESULTS}

In Figure 1 is shown a comparison of McGill II and De Gowin's solution and of several variants of ACD-I solution with ACD-I mixture, portrayed graphically by plotting the values of each of the simultaneously determined indices in the solution under test against the corresponding values of the same blood in ACD-I solution. In the case of equal performance the plot will lie on a straight line equidistant from abscissa and ordinate, i.e., the diagonal. Such lines are drawn in each of the graphs. For the properties of the red cell which show a tendency to increase in numerical value during storage, such as thickness, hemolysis, and potassium content of plasma, an arrow-point directed away from the origin is provided, while for those properties which tend to decrease during storage, such as the adenosine triphosphate and potassium content of cells and their glycolysis rate, the arrow is pointed toward the origin of the diagonal. The data on bloods stored in solutions inferior in preservative quality to ACD-I mixture would tend to be above the diagonal for cell characteristics which tend to increase in numerical value during storage and below it for those which tend to decrease. It may be seen that erythrocytes in McGill II solution were inferior in preservation to those in ACD-I solution with respect to hemolysis in 0.6 per cent $\mathrm{NaCl}$ solution, thickness, adenosine triphosphate and potassium content. With respect to glycolysis the data require additional interpretation. Erythrocytes in McGill II solution, as in other neutral mixtures, initially glycolyze at a rate greater than those in ACD-I solution, but their glycolyzing power is exhausted sooner. The values for McGill II solution lying above the diagonal line refer to blood samples after only short periods of storage, while those below the line refer to bloods stored for longer periods of time, when their glycolyzing power was exhausted, while it still persisted in a parallel blood sample in
ACD-I solution. The data on the potassium content of the plasma appear to be at variance with the other indices but it should be remembered that blood stored in McGill II solution is diluted to the extent of 50 per cent, entailing an almost 2-fold dilution of the plasma. Data on hemolysis of red cells in De Gowin's solution are omitted from presentation since the osmotic behavior of erythrocytes in this solution differs markedly from that in the other solutions tested. Values for other properties of erythrocytes in this solution are also somewhat difficult to interpret because of the great increase in their cellular volume. Those charted have been corrected for the increase in volume. It appears that the cells in De Gowin's solution increased progressively in thickness during storage and that their adenosine triphosphate content and glycolyzing power became exhausted earlier than in parallel blood samples stored in ACD-I solution. The potassium content of the cells decreased at a rapid rate, probably because of the low content of electrolyte of the solution, while the potassium content of the plasma, which represents a 3.5-fold dilution of the original, was lower than in all other solutions. Solution ACD-IA, the most concentrated modification of ACD-I mixture, appears also somewhat inferior to ACD-I solution in its performance, as judged by hemolysis, thickness, and glycolysis rate. Other indices did not show significant differences. The comparatively good preservation of blood in solution IF, which contains lactic acid in amounts equal to those accumulated during extended periods of storage, although inferior to ACD-I, suggests that lactic acid per se is not an important deteriorative factor. None of the other solutions tested appeared significantly different in preservative quality from ACD-I solution.

In Figure 2 are shown the changes of red cells during storage at $4^{\circ}$ and $25^{\circ} \mathrm{C}$. in Alsever's solution and at $4^{\circ} \mathrm{C}$. in ACD-I mixture. It may be seen that erythrocytes of blood in Alsever's solution were similar in their preservation to those in ACD solution until about the fourteenth day when both were kept at $4^{\circ} \mathrm{C}$. Beyond this time they deteriorated at an increasingly rapid rate. The effects of storage of $25^{\circ} \mathrm{C}$. are apparent in regard to all indices studied, storage for 2 days at this temperature being approximately equivalent to 2 weeks storage at $4^{\circ} \mathrm{C}$. It may be mentioned 

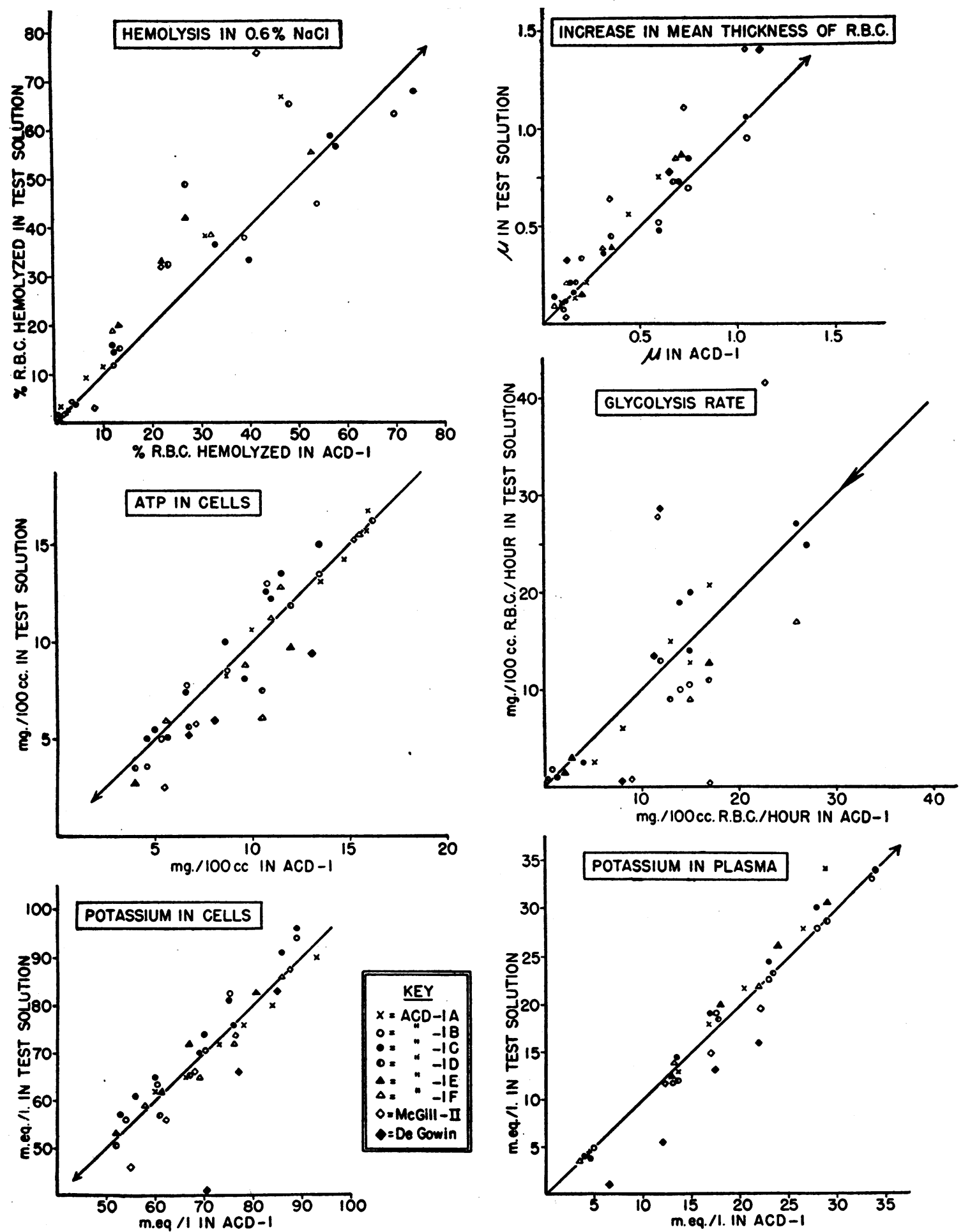

Fig. 1. Comparison of Several Acid and Neutral Citrate-Glucose Solutions with ACD-I Solution 

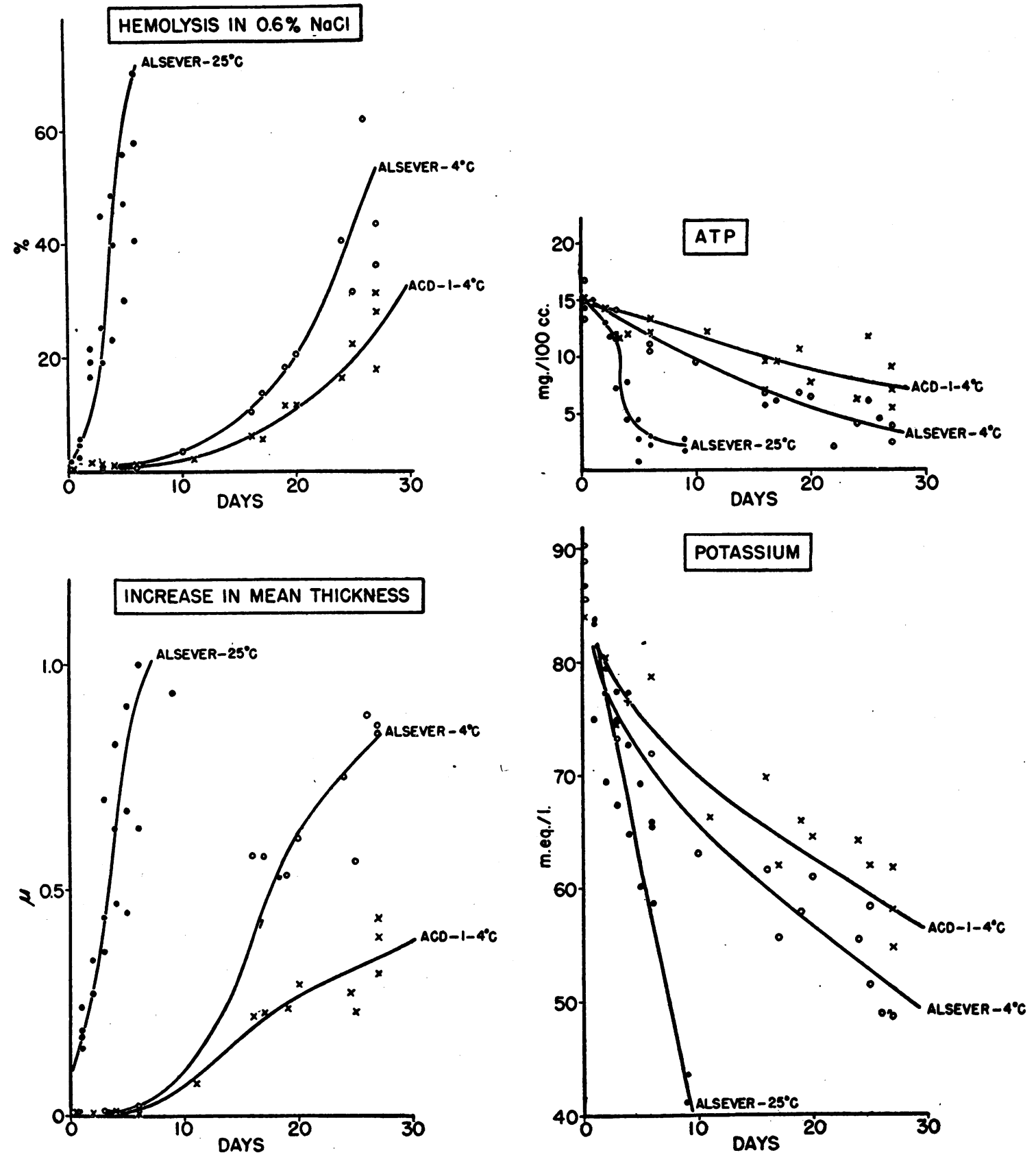

Fig. 2. Changes in Cellular Indices in Alsever Solution at $4^{\circ}$ and $25^{\circ} \mathrm{C}$. and in ACD-I Solution at $4^{\circ} \mathrm{C}$.

here that even after storage periods of 10 days at room temperature spontaneous hemolysis was of small degree, indicating that this measurement is a fallacious index under such circumstances. From the data the conclusion may be drawn that non-refrigeration has a catastrophic effect on the functional state of the cell.
Osmotic characteristics of preservative solutions and corpuscular volume of erythrocytes

In Table II is given a description of the various ACD mixtures and in Table III, of the neutral preservatives from the standpoint of their osmotic and electrolyte composition. In Table IV is pre- 
sented a summary of the predicted and observed values of corpuscular volume and hemoglobin concentration of erythrocytes of stored bloods in 5 acid and 3 neutral preservative solutions. As may

TABLE II

Osmolarity of various $A C D$ preservative solutions and resulting changes in the osmotic and electrolyte concentration of blood

\begin{tabular}{|c|c|c|c|c|c|c|}
\hline ACD solution & I & IA & IB & IC & ID & IE \\
\hline $\begin{array}{l}\text { Sodium citrate, } m M \text {. per liter } \\
\text { Sodium citrate, } m \text {. osm. per liter } \\
\text { Citric acid, } m \text {. osm. per liter } \\
\text { Glucose, } m \text {. osm. per liter }\end{array}$ & $\begin{array}{r}45 \\
181 \\
22 \\
167 \\
\end{array}$ & $\begin{array}{r}112 \\
450 \\
55 \\
418\end{array}$ & $\begin{array}{r}38 \\
152 \\
30 \\
167\end{array}$ & $\begin{array}{r}68 \\
272 \\
37 \\
278\end{array}$ & $\begin{array}{r}30 \\
120 \\
38 \\
167\end{array}$ & $\begin{array}{r}64 \\
255 \\
50 \\
278\end{array}$ \\
\hline $\begin{array}{l}\text { Total osmolarity of solution, } m \text {.osm. per } \\
\text { liter } \\
\text { Total osmolarity of solution, per cent of } \\
\text { initial blood } \\
\text { tonicity }\end{array}$ & $\begin{array}{r}119 \\
203 \\
66\end{array}$ & $\begin{array}{l}298 \\
505 \\
163\end{array}$ & $\begin{array}{r}113 \\
182 \\
59\end{array}$ & $\begin{array}{l}189 \\
309 \\
100\end{array}$ & $\begin{array}{r}105 \\
158 \\
51\end{array}$ & 58 \\
\hline $\begin{array}{l}\text { Osmolarity of blood } \\
\text { after mixing, }{ }^{* * *} m \text {. osm. per liter } \\
\text { Osmolarity of blood } \\
\text { after mixing. per cent of initial } \\
\text { Electrolyte concentration of blood after } \\
\text { mixing. per cent of initial }\end{array}$ & $\begin{array}{r}324 \\
104 \\
92\end{array}$ & 122 & $\begin{array}{l}319 \\
103\end{array}$ & $\begin{array}{l}354 \\
114\end{array}$ & $\begin{array}{c}314 \\
101\end{array} \mid$ & 100 \\
\hline
\end{tabular}

* Effective tonicity is designated the osmotic concentration of substances which permeate the cell membrane very slowly, if at all. In this instance its value was̀ calculated on the assumption that the electrolytes, but not glucose, conform to this condition.

** Calculated on the basis of an initial concentration of 310 milliosmols per liter of water in blood, and of a water content of $\mathbf{0 . 8 0}$ gram per gram of blood.

TABLE III

Osmolarity of 3 neutral preservative solutions and resulting changes in the osmotic and electrolyte concentration of blood

\begin{tabular}{|c|c|c|c|}
\hline Solution & $\begin{array}{l}\text { Al- } \\
\text { sever }\end{array}$ & $\begin{array}{c}\text { De- } \\
\text { Gowin }\end{array}$ & $\begin{array}{l}\text { Mc- } \\
\text { Gill } \\
\text { II }\end{array}$ \\
\hline $\begin{array}{l}\text { Sodium citrate, } m M \text {. per liter } \\
\text { Sodium citrate, m. osm. per liter } \\
\text { Citric acid, } m \text {. osm. per liter } \\
\text { Other ingredients, } m \text {. osm. per liter } \\
\text { Glucose, } m . \text { osm. per liter }\end{array}$ & $\begin{array}{c}27 \\
108 \\
0.4 \\
144^{*} \\
114\end{array}$ & $\begin{array}{l}14.5 \\
58 \\
261\end{array}$ & $\begin{array}{l}44 \\
174 \\
62 * * \\
120\end{array}$ \\
\hline $\begin{array}{l}\text { Total osmolarity of solution, m. osm. per liter } \\
\text { Total osmolarity of solution, per cent of initial } \\
\text { blood tonicity } \\
\text { Effective tonicity,*** m. osm. per liter } \\
\text { Effective tonicity, per cent of initial blood } \\
\text { tonicity }\end{array}$ & $\begin{array}{r}366 \\
118 \\
252 \\
81\end{array}$ & $\begin{array}{r}319 \\
103 \\
58 \\
19\end{array}$ & $\begin{array}{r}356 \\
115 \\
236 \\
76\end{array}$ \\
\hline $\begin{array}{l}\text { Osmolarity of blood after mixing, }+ \text { m. osm. per liter } \\
\text { Osmolarity of blood after mixing, per cent of } \\
\text { initial } \\
\text { Electrolyte concentration of blood after mixing, } \\
\text { per cent of initial }\end{array}$ & $\begin{array}{r}341 \\
110 \\
90\end{array}$ & $\begin{array}{r}316 \\
102 \\
47\end{array}$ & $\begin{array}{r}328 \\
106 \\
91\end{array}$ \\
\hline
\end{tabular}

* Sodium chloride.

** Isotonic sodium phosphate solution $\mathrm{pH} 7.4$.

*** Effective tonicity is designated the osmotic concentration of substances which permeate the cell membrane very slowly, if at all. In this instance its value was calculated on the assumption that the electrolytes, but not glucose, conform to this condition.

+ Calculated on the basis of an initial concentration of 310 milliosmols per liter of water in blood, and of a water content of 0.80 gram per gram of blood.
TABLE IV

Corpuscular volume and hemoglobin concentration of erythrocytes stored in various preservative solutions

\begin{tabular}{|c|c|c|c|c|c|c|}
\hline \multirow{2}{*}{ Solution } & \multirow{2}{*}{$\begin{array}{c}\text { Stor- } \\
\text { age } \\
\text { period }\end{array}$} & \multicolumn{2}{|c|}{$\begin{array}{c}\text { Corpuscular } \\
\text { volume }\end{array}$} & \multicolumn{2}{|c|}{$\begin{array}{l}\text { Corpuscular } \\
\text { hemoglobin } \\
\text { concentration }\end{array}$} & \multirow{2}{*}{$\underset{\mathrm{pH}}{\text { Plasma }}$} \\
\hline & & $\begin{array}{c}\text { Ob- } \\
\text { served }\end{array}$ & $\begin{array}{c}\text { Pre- } \\
\text { dicted }\end{array}$ & $\begin{array}{c}\text { Ob- } \\
\text { served }\end{array}$ & $\begin{array}{c}\text { Pre- } \\
\text { dicted }\end{array}$ & \\
\hline & days & $\begin{array}{l}\text { per cent } \\
\text { of } \\
\text { normal }\end{array}$ & $\begin{array}{l}\text { per cent } \\
\text { of } \\
\text { normal* }\end{array}$ & $\begin{array}{l}\text { per cent } \\
\text { of } \\
\text { normal* }\end{array}$ & $\begin{array}{l}\text { per cent } \\
\text { of } \\
\text { normal* }\end{array}$ & \\
\hline ACD-IA & $\begin{array}{c}0 \\
20-30\end{array}$ & $\begin{array}{l}100 \\
100\end{array}$ & $\begin{array}{l}101 \\
101\end{array}$ & $\begin{array}{r}100 \\
99\end{array}$ & $\begin{array}{l}100 \\
100\end{array}$ & $\begin{array}{l}7.05 \\
6.50\end{array}$ \\
\hline ACD-IB & $\begin{array}{c}0 \\
20-30\end{array}$ & $\begin{array}{l}109 \\
108\end{array}$ & $\begin{array}{l}117 \\
117\end{array}$ & $\begin{array}{l}92 \\
92\end{array}$ & $\begin{array}{l}84 \\
84\end{array}$ & $\begin{array}{l}6.82 \\
6.41\end{array}$ \\
\hline ACD-IC & $\begin{array}{c}0 \\
20-30\end{array}$ & $\begin{array}{l}106 \\
107\end{array}$ & $\begin{array}{l}106 \\
106\end{array}$ & $\begin{array}{l}94 \\
94\end{array}$ & $\begin{array}{l}94 \\
94\end{array}$ & $\begin{array}{l}7.00 \\
6.52\end{array}$ \\
\hline ACD-ID & $\begin{array}{c}0 \\
20-30\end{array}$ & $\begin{array}{l}118 \\
116\end{array}$ & $\begin{array}{l}119 \\
119\end{array}$ & $\begin{array}{l}82 \\
84\end{array}$ & $\begin{array}{l}82 \\
82\end{array}$ & $\begin{array}{l}6.67 \\
6.32\end{array}$ \\
\hline ACD-IE & $\begin{array}{c}0 \\
20-30\end{array}$ & $\begin{array}{l}107 \\
107\end{array}$ & $\begin{array}{l}106 \\
106\end{array}$ & $\begin{array}{l}92 \\
92\end{array}$ & $\begin{array}{l}94 \\
94\end{array}$ & $\begin{array}{l}6.84 \\
6.43\end{array}$ \\
\hline Alsever & $\begin{array}{c}0 \\
20-30\end{array}$ & $\begin{array}{l}109 \\
114\end{array}$ & $\begin{array}{l}110 \\
116\end{array}$ & $\begin{array}{l}91 \\
88\end{array}$ & $\begin{array}{l}90 \\
87\end{array}$ & $\begin{array}{l}7.27 \\
6.81\end{array}$ \\
\hline McGill II & $\begin{array}{c}0 \\
20-30\end{array}$ & $\begin{array}{l}108 \\
115\end{array}$ & $\begin{array}{l}110 \\
116\end{array}$ & $\begin{array}{l}91 \\
87\end{array}$ & $\begin{array}{l}91 \\
86\end{array}$ & $\begin{array}{l}7.34 \\
6.79\end{array}$ \\
\hline De Gowin & $\begin{array}{c}0 \\
20-30\end{array}$ & $\begin{array}{l}142 \\
163\end{array}$ & 213 & $\begin{array}{l}74 \\
63\end{array}$ & 47 & $\begin{array}{l}7.38 \\
6.71\end{array}$ \\
\hline
\end{tabular}

* The values in heparinized blood samples have been designated as "normal."

be seen from the data, agreement between observation and theory was close for all solutions which differed in a minor degree only from the tonicity of blood. The results indicate that osmotic effects and membrane equilibria affect independently and in a strictly additive manner the corpuscular volum of erythroycytes. The constancy of the cell volume during storage in all acidified solutions and the limited increase in the neutral ones are in consonance with the hypothesis, that cations on the acid side of the iso-ionic point of hemoglobin are lost from the cell in proportion to the ionization of hemoglobin.

\section{SUM MARY}

In a study of 6 acid preservative solutions, none was found which exhibited better preservative qualities than ACD-I solution. There was some indication that one of the modifications, which was hypertonic, resulted in inferior preservation of erythrocytes. Lactic acid did not appear to be a deteriorative factor of major importance. 
A comparison of Alsever's solution with ACD-I solution indicated that it possessed inferior preservative qualities. The effect of storage of blood at $25^{\circ} \mathrm{C}$. in Alsever's solution was a great acceleration of deteriorative processes within the red cell.

A study of the osmotic characteristics of the various preservative solutions and of the corpuscular volume of erythrocytes indicated that addition of Alsever's and McGill II solutions resulted in only minor deviations of the electrolyte concentration of blood from the normal, while the addition of De Gowin's solution produced a decrease of the electrolyte concentration to less than $1 / 2$ of normal with profound changes in the osmotic behavior of the cells. The observed corpuscular volume of erythrocytes in 5 acid and 2 neutral preservatives was in good agreement with predictions based on consideration of the osmotic and membrane equilibria of the red cell and on the assumption that red cells lose cations below the iso-ionic point of hemoglobin in amounts proportional to its ionization as a cation.

\section{BIBLIOGRAPHY}

1. Rapoport, S., Dimensional, osmotic and chemical changes of erythrocytes in stored blood. I. Blood preserved in sodium citrate, neutral, and acid citrate-glucose (ACD) mixtures. J. Clin. Invest., 1947, 26, 591.

2. Loutit, J. F., Mollison, P. L., and Young, I. M., Citric acid-sodium citrate-glucose mixtures for blood storage. Quart. J. Exper. Physiol., 1943, 32, 183.

3. Loutit, J. F., and Mollison, P. L., Advantages of a disodium-citrate-glucose mixture as a blood preservative. Brit. M. J., 1943, 2, 744.

4. Alsever, J. B., and Ainslie, R. B., A new method for the preparation of dilute blood plasma and the operation of a complete transfusion service. New York State J. Med., 1941, 41, 126.

5. Kendrick, D. B., Jr., Elliott, J., Reichel, J., Jr., and Vaubel, E. K., Supply of preserved blood to European Theater of Operations. Bull. U. S. Army M. Dept., 1945, No. 84, 66.

6. De Gowin, E. L., Harris, J. E., and Plass, E. D., Studies on preserved human blood. I. Various factors influencing hemolysis. J. A. M. A., 1940, $114,850$.

7. Denstedt, O. F., Osborne, D. E., Stansfield, H., and Rochlin, I., The survival of preserved red cells after transfusion. Anesthesiology, 1944, 5, 237. 